\title{
Status of the Diadromous Fish of the Iberian Peninsula: Past, Present and Trends
}

\author{
Micaela Mota ${ }^{1,2,3, *}$, Eric Rochard ${ }^{4}$ and Carlos Antunes ${ }^{2,3}$ \\ ${ }^{1}$ ICBAS-Institute of Biomedical Sciences of Abel Salazar; University of Porto, Rua de Jorge Viterbo Ferreira \\ 228, 4050-313 Porto, Portugal. \\ ${ }^{2}$ CIMAR/CIIMAR-Interdisciplinary Centre of Marine and Environmental Research, University of Porto, Rua \\ dos Bragas 289, 4050-123 Porto, Portugal. \\ ${ }^{3}$ Aquamuseu do Rio Minho, Parque do Castelinho, 4920-290 Vila Nova de Cerveira, Portugal. \\ ${ }^{4}$ Irstea-EPBX Estuarine Ecosystems and Diadromous Fish research unit. 50 Avenue de Verdun 33612 Cestas, \\ France.
}

*Corresponding author: mmota@ciimar.up.pt

Received: 01/04/14

Accepted: $30 / 01 / 15$

\begin{abstract}
Status of the Diadromous Fish of the Iberian Peninsula: Past, Present and Trends

We examined the past, present and predictable status of diadromous fishes on the Iberian Peninsula, with a focus on the species inhabiting the Minho River. Data on six diadromous species (five anadromous, one catadromous) were collected. Due to population extinction and abundance reductions, many species are now classified as threatened or endangered. Many populations persisted at only drastically reduced abundance levels. Habitat loss (especially damming), overfishing, pollution and, increasingly, climate change contributed to this decline of diadromous fish. Although there is still limited information on the conservation status, migratory behaviour, biology and ecology of diadromous fish in the Iberian Peninsula, and except for Sea lamprey, which have shown a recent rise in population size in some rivers, it is clear that diadromous fish populations are showing a general trend towards decline. Overall, Iberian diadromous species have suffered a great decline since the $20^{\text {th }}$ century. Although Iberian Sea lamprey populations are not critically endangered or endangered, they are facing a high risk of extinction in the wild in the medium-term future. Atlantic salmon populations experienced the first serious decline in the $19^{\text {th }}$ century, and the decline has continued during the $20^{\text {th }}$ century. Despite the importance of Sea trout in Galician (NW Spain) and North Portugal, to date, few studies have been performed. The reduction in the Portuguese Sea trout populations may have reached $98 \%$ of the number of mature individuals. Allis and Twaite shads were, at times, of large economic importance, but currently, some Iberian populations are severely extirpated. For example, in the Minho River, the catches have decreased by about $90 \%$ since the $50^{\text {th }}$ decade of the $20^{\text {th }}$ Century. In the Iberian Peninsula, eel disappeared from important Iberian catchment areas, and during the 1980s, commercial fishing showed a downward trend. As most of the larger Iberian rivers cross international borders, the management and conservation of migratory fish species on transboundary rivers should be based on international cooperative and concerted efforts.
\end{abstract}

Key words: Diadromous fishes, Iberian Peninsula, decline, habitat loss.

\section{RESUMO}

\section{Estado dos peixes diádromos da Península Ibérica: Passado, Presente e Tendências}

Examinámos o passado, o presente e o estatuto previsível dos peixes diádromos da Península Ibérica, com foco nas espécies presentes no rio Minho. Foram analisados dados de seis espécies diádromas (cinco anádromas, uma catádroma). Devido à extinção e diminuição da abundância de populações, muitas espécies estão atualmente classificadas como ameaçadas ou em perigo. Muitas populações permaneceram em níveis de abundância drasticamente reduzidos. Perda de habitat (principalmente pela construção de barragens), sobrepesca, poluição e, gradualmente, as alterações climáticas, contribuíram para o declínio das espécies diádromas. Embora o conhecimento sobre o estado de conservação, comportamento migratório, biologia e ecologia dos peixes diádromos seja reduzido na Península Ibérica e com exceção da lampreia que mostrou um aumento populacional em alguns rios, é evidente que as populações de peixes diádromos têm mostrado uma tendência geral 
Mota et al.

de declínio. Em geral, as espécies diádromas ibéricas sofreram uma grande diminuição a partir do século XX. Embora as populações de lampreia marinha não estejam criticamente em perigo ou em perigo, elas enfrentam um alto risco de extinção a um futuro a médio prazo. As populações de salmão do Atlântico registaram o seu primeiro declínio no século XIX, que continuou durante o século XX. Apesar da importância da truta marisca na Galiza (NW de Espanha) e no Norte de Portugal, poucos estudos foram realizados até ao momento. A redução das populações portuguesas de truta marisca pode ter atingido $98 \%$ do número de indivíduos maduros. Sável e savelha tiveram, em tempos, grande importância económica, mas sabe-se que atualmente algumas populações ibéricas foram severamente extirpadas. Por exemplo, no rio Minho, as capturas diminuíram cerca de $90 \%$ desde a década de 50 do século XX. Na Península Ibérica a enguia desapareceu das grandes bacias hidrográficas e durante os anos 80, a pesca comercial mostrou uma tendência de diminuição. Como a maioria dos grandes rios ibéricos cruzam fronteiras, a gestão e conservação das espécies de peixes migratórios em rios internacionais deve ser baseada nos esforços concertados e na cooperação internacional.

Palavras chave: Peixes diádromos, Península Ibérica, declínio, perda de habitat.

\section{INTRODUCTION}

Although diadromous fishes represent less than $1 \%$ of the world's fish fauna, their value to humans exceeds this proportion by far (Limburg $\&$ Waldman, 2009). The diadromous fish species Sea lamprey Petromyzon marinus (Linnaeus, 1758), Atlantic salmon Salmo salar (Linnaeus, 1758), European eel and glass eel Anguilla anguilla (Linnaeus, 1758), Allis shad Alosa alosa (Linnaeus, 1758), Twaite shad Alosa fallax (Lacepède, 1803) and Sea trout Salmo trutta (Linnaeus, 1758) have a huge economic and cultural importance in several Iberian Peninsula (IP) basins, especially in the Minho River (NW IP). Apart from the mentioned species, other diadromous species are present on the IP (e.g., Doadrio, 2002; Cabral et al., 2006; Doadrio et al., 2011). The thin lipped mullet Liza ramada (Risso, 1810) and the European flounder Platichthys flesus (Linnaeus, 1758) are exploited species, despite their lower economic value, while the River Lamprey Lampetra fluviatilis (Linnaeus, 1758) is an unexploited species. The European Sturgeon Acipenser sturio (Linnaeus, 1758) was formerly a commercially important species and was present in several IP rivers; the two last records were of an individual near the mouth of the Guadalquivir (Spain) in 1992 (Almaça \& Elvira, 2000, Doadrio et al., 2011) and a large specimen at Gijon (Asturias) in 2010 (Loza \& Pis, 2010).

Diadromous fish use successively freshwater, estuarine and marine habitats, which exposes them to environmental impacts and fishing in all three habitats. However, this also gives them opportunities to disperse. The successful completion of such a life cycle requires favourable conditions in both freshwater and marine environments. The transition from fresh to marine habitats, and back, is particularly critical due to urban and industrial developments in coastal zones, which are the most intensively modified and threatened ecosystems (McDowall, 1999).

During the last century, we observed a drastic decline in the abundance of diadromous fish populations (Lobón-Cervia, 1999; Groot, 2002; Baglinière et al., 2003; Hendry \& Cragg-Hine, 2003; Beaulaton et al., 2008; OSPAR, 2008; OSPAR, 2009). Several basins have been cleared of most of their diadromous fish species as a result of habitat fragmentation due to dam construction (Nicola et al., 1996; Larinier, 2001) and associated variability in flow regimes (Lundqvist et al., 2008), deterioration in water quality in industrialized areas (Baglinière et al., 2003; Maes et al., 2008) and destruction of spawning habitats caused by sand and gravel extractions. Their migrations through estuaries increase diadromous fish vulnerability, as their physical concentration increases their catchability, with the associated risks of overexploitation (McDowall, 1999) and unsustainable fisheries (Rochard et al., 1990).

In Galicia (NW Spain), the available area for diadromous fish represents only $12.5 \%$ of their potential original distribution area (Hervella \& Caballero, 1999), and it is even less for the rest of the IP (Fig. 1). Currently, in Portugal, only 3.8\% 
of the total length of a drainage basin is available for eel (Eel Management Plan -EMP, 2010), and even less for other diadromous fish species with more limited capacity to get over obstacles and more restricted favorable habitats such as the Allis shad. In the Minho basin, the accessible area to diadromous species has decreased from about $17000 \mathrm{~km}^{2}$ (at the beginning of the twentieth century) to around $1000 \mathrm{~km}^{2}(6 \%)$ currently. For species using only the main channel of the Minho River to migrate (e.g., Allis shad), the accessible habitat represents no more than $26.6 \%$ of the pristine habitat.

Recently, climate changes are reported to be an additional factor contributing to diadromous fish extinction (Boisneau et al., 2008; Jonsson \& Jonsson, 2009; Lassalle \& Rochard, 2009; Lassalle et al., 2010). Béguer et al. (2007) pointed out that, within the European context, the tem- perature is the main factor structuring the diadromous fish assemblages through hydrographical basins.

In this paper, we compiled information from the literature, official statistics of captures and unpublished data in order to summarize the past and present status of the commercially most important and exploited diadromous fish of the IP: Sea lamprey P. marinus L., Atlantic salmon $S$. salar L., European eel and glass eel A. anguilla L., Allis shad (A. alosa L.), Twaite shad (A.fallax L.) and Sea trout $S$. trutta L. We aim to summarize the information at the IP scale, with a particular focus on the Minho River system. Apart from being one of the most well-preserved large Iberian rivers, there is a good long-term series of fishery data, and recent scientific research allows for better knowledge development on diadromous species.

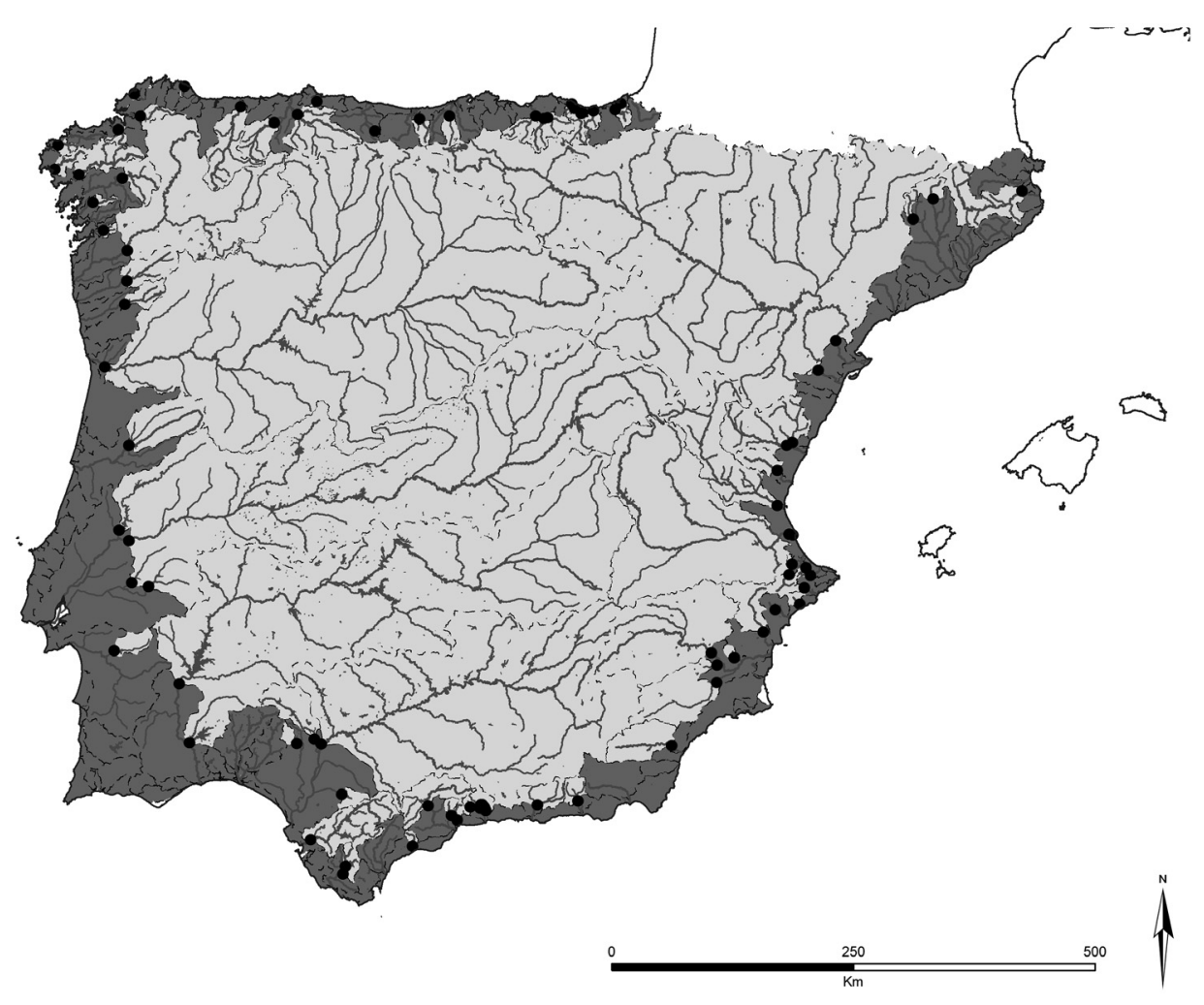

Figure 1. The hydrographical network of the IP, showing potential habitats for diadromous species. Dots: first obstacle in the main course of the rivers; Dark grey: available habitat for diadromous fish; Bright grey: inaccessible habitat for diadromous fish. Rede hidrográfica da PI mostrando o habitat potencial para as espécies diádromas. Pontos: primeiro obstáculo no curso principal dos rios; Cinzento escuro: habitat disponível para os peixes diádromos; Cinzento claro: habitat inacessível para os peixes diádromos. 


\section{SEARCH FOR IP DIADROMOUS FISH INFORMATION}

For the IP, data on historical and present numbers of diadromous fish are scarce, and the availability of information seems to be associated with their commercial relevance. All diadromous species regularly encountered in the study area were con-
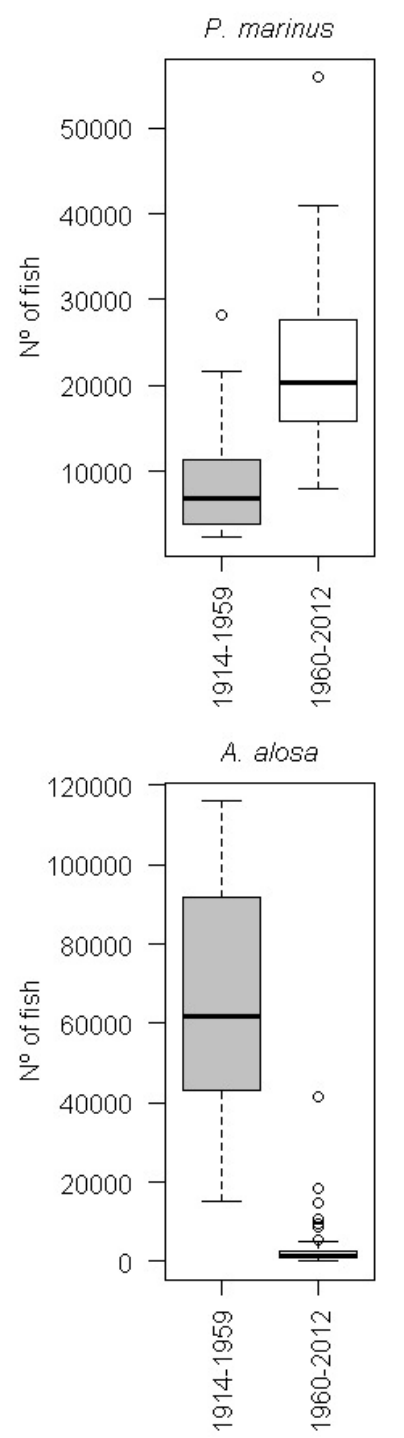

sidered. This list was based on the Red Books of Portugal (Cabral et al., 2006) and Spain (Doadrio, 2002).

We synthesized WEB information on the current status of IP diadromous fish using the following databases and search tools. Google Scholar was used for general bibliographic methods using citations and other more gen-
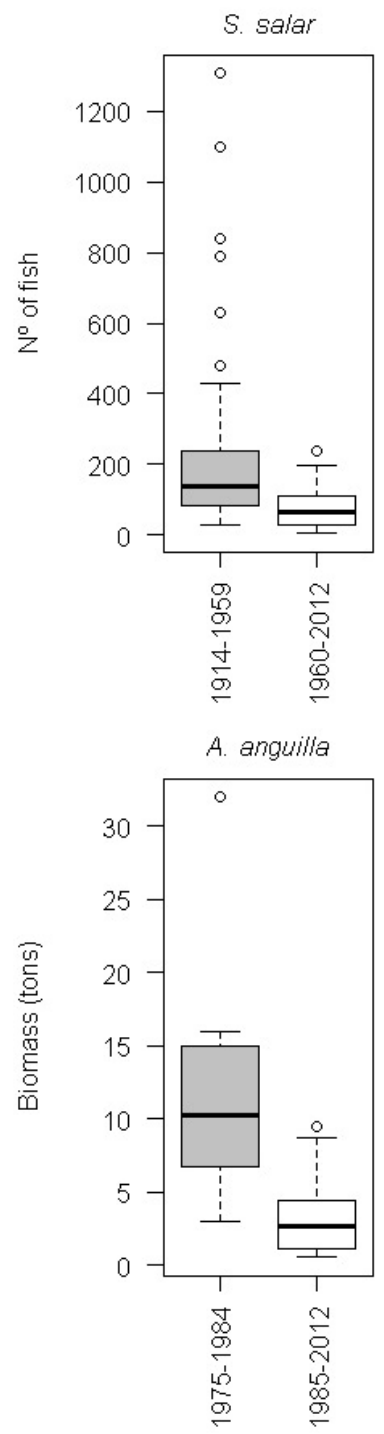

Figure 2. Minho River landings (in $n^{\circ}$ of fish) of Sea lamprey, Atlantic salmon and Allis shad and (in tonnes) of Glass eel. Data are shown separately for the first half of the $20^{\text {th }}$ century (1914-1959) and the second half of the 20 $0^{\text {th }}$ century (1960-2012) for Sea lamprey, Atlantic salmon and Allis shad. The Glass eel data were separated according to the first major drop observed in the landings. Capturas de lampreia marinha, salmão do Atlântico, sável (em $n^{o}$ de peixes) e de enguia de vidro (em toneladas). Os dados apresentados compreendem a primeira metade do século XX (1914-1959) e a segunda metade do século XX (1960-2012) para a lampreia, salmão do Atlântico e sável. Os dados da enguia de vidro foram separados de acordo com a maior quebra observada nas capturas. 
eral referencing as the common and scientific name of the diadromous species; ScienceDirect, Scopus and PubMed were used for advanced searches, using keywords and back searching. To refine results, the search was restricted to a "cited reference" search.

However, as data were variable in quality and quantity and difficult to obtain for most species, information from books, unpublished literature and other documents was gathered from several sources, such as university and museum libraries. Additional published and unpublished data were provided by scientists working in this field (see Acknowledgments).

Minho River time-series data sets were collected mostly from official data of the local maritime authorities, which had an especially rich and long set of diadromous species landings (from 1914 for Allis shad, Sea lamprey and salmon and from 1975 for glass eel). These data sets refer to the labile fishing periods for each fish species, which may vary over the years. This information is, however, inaccurate and underestimates the real numbers of captures, which are screened by fishermen.

Although the quality and quantity of time series data sets vary, the trend is almost always the same, with diadromous fishes in decline, often to historic lows.

Since the second half of the $20^{\text {th }}$ century, the data for diadromous species in the Minho River are restricted to official statistics of fishery landings (Fig. 2). As this information is imprecise and subject to bias, there is an urgent need for additional information concerning these species.

\section{IBERIAN PENINSULA DIADROMOUS FISH STATUS}

\section{P. marinus}

Sea lamprey is widely distributed on both sides of the North Atlantic (Quintella, 2006; Beaulaton et al., 2008), occurring also in Mediterranean and Atlantic Canadian basins (Halliday, 1991). Similar to other migratory fish, this species is common along large Iberian rivers, occurring in several Spanish basins along the Cantabrian, Atlantic, and Mediterranean coasts (Fig. 3). Although the Sea lamprey inhabits most Cantabrian rivers, it is missing in some areas of País Vasco, Cantabria and in some Galician rivers (Doadrio et al., 2011; Perea et al., 2011). According to Cobo (2009), this species is still present in several Galician rivers and in Asturias (Rodríguez-Muñoz, 1992). More recently, juvenile specimens were collected from the Guadiaro River, confirming the occurrence of Sea lamprey reproduction in southern Spain (Perea et al., 2011). In Portugal, this species is present in all of the most basins and is more abundant in the northern Sado River (Almeida et al., 2002a; Quintella et al., 2003; Almeida et al., 2008). The southern natural distribution limit in Portugal is near the Guadiana River (Hardisty, 1986; Almeida et al., 2008).

As well as for other migratory fish common along large Iberian rivers, the available habitat to the Sea lamprey is currently decreasing due to the construction of dams, which represents a loss of habitat of around $80 \%$ (Mateus et al., 2012) because, in general, the fish pass systems in dams do not work. For example, the access to the main channel of the river Tagus (which flows through Portugal and Spain) by the Sea lamprey is currently restricted to the Portuguese portion of this river because of two dams blocking access to its Spanish part (Assis, 1990). In Portugal, the usable habitat does not exceed $588 \mathrm{~km}$ (Mateus et al., 2012).

The main threats to Galician Sea lamprey populations are also the construction of dams, as well as gravel extraction in the freshwater larvalgrowth areas, overfishing and poaching (Cobo, 2009).

The Sea lamprey has been considered to be, for quite a long time, a gastronomic delicacy in Europe (Kelly \& King, 2001; Maitland, 2003), which has led to intense commercial exploitation in some countries. It is a commercially important and valuable species in Spain and Portugal (Kelly \& King, 2001; Maitland, 2003); in Portugal, a single fish can cost as much as $45 €$ (Andrade et al., 2007) every year at the beginning of the fishing season. During the peak of migration, the main Portuguese estuaries and rivers are 
Table 1. Sea Lamprey conservation status at Portuguese (national) and Spanish (autonomous region) levels. Estatuto de conservação da lampreia marinha em Portugal (nacional) e Espanha (regiões autónomas).

\begin{tabular}{llll}
\hline & Region & Conservation status & Regulation document \\
\hline Portugal & $\begin{array}{l}\text { National } \\
\text { Galicia autonomous } \\
\text { region }\end{array}$ & $\begin{array}{l}\text { Vulnerable } \\
\text { Vulnerable }\end{array}$ & $\begin{array}{l}\text { Red Book of endangered species } \\
\text { Galician Catalogue of Endangered Species }\end{array}$ \\
& $\begin{array}{l}\text { Asturias autonomous } \\
\text { region }\end{array}$ & Vulnerable & $\begin{array}{l}\text { Regional Catalogue of Endangered Vertebrate Fauna of } \\
\text { the Principality of Asturias }\end{array}$ \\
& $\begin{array}{l}\text { Extremadura } \\
\text { autonomous region }\end{array}$ & Endangered & $\begin{array}{l}\text { Annex I of Regional Catalogue of Endangered Species of } \\
\text { the Extremadura }\end{array}$ \\
& $\begin{array}{l}\text { Navarra autonomous } \\
\text { region }\end{array}$ & Special interest & Navarra Registration of the Vertebrate Wildlife \\
\hline
\end{tabular}

crowded with fishermen and poachers (Almeida et al., 2002a). Next to the reduction of a suitable habitat due to dam construction, this intense fishery constitutes the main threat to the survival of this species in Portuguese river basins (Almeida et al., 2002b; Andrade et al., 2007).

In European, the Portuguese, Spanish and French (OSPAR, 2009) Sea lamprey populations are not considered as endangered but are facing, in the medium term, a high risk of extinction in the wild (Lassalle et al., 2008). The status of Spanish Sea lamprey populations remains poorly known, but at the Spanish autonomous region level, as well as in Portugal, this species benefits from several conservation regulations (Table 1).

Even though the current abundances of Sea lamprey are still far below the historic levels (OSPAR, 2009), some European rivers, such as

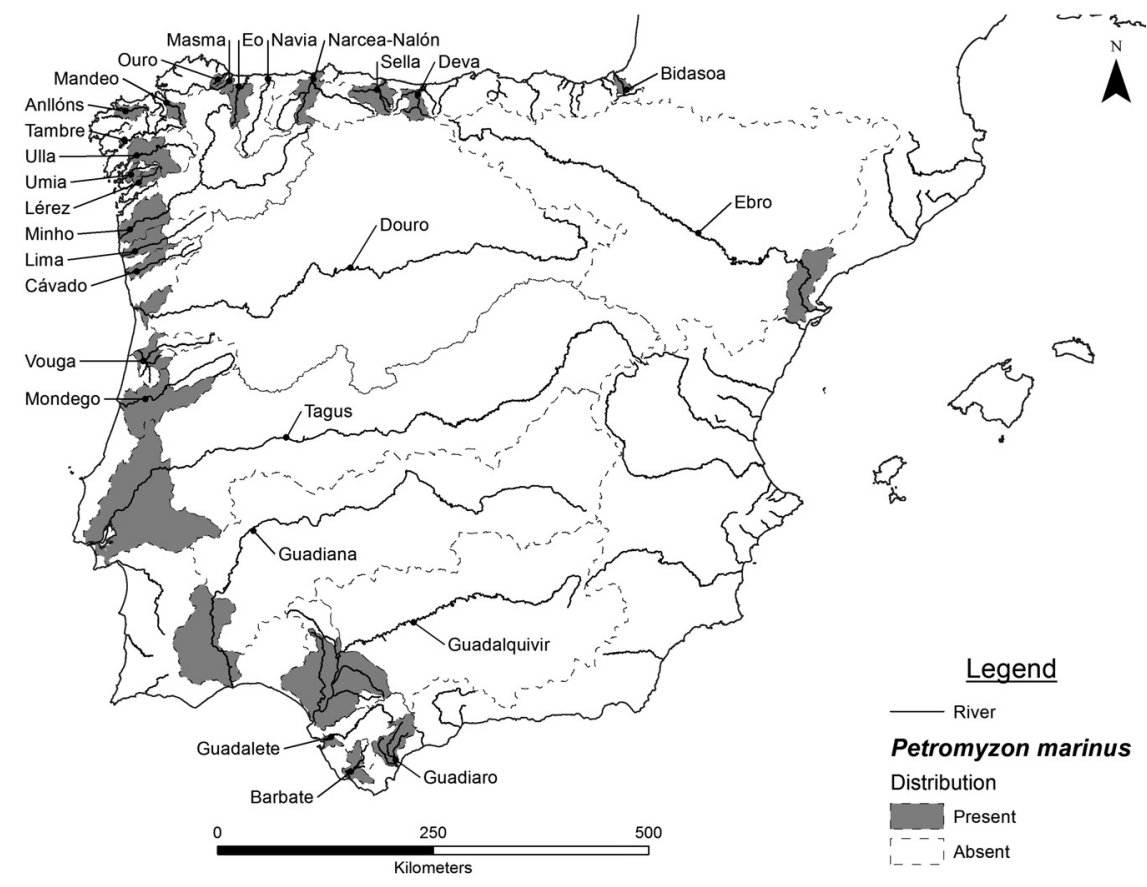

Figure 3. Sea Lamprey distribution on the IP, showing areas where the species is present or absent. Distribuição da lampreia marinha na PI, mostrando áreas onde está presente e ausente. 
the Garonne, Adour, Vilaine and Rhine, have shown a recent rise in the population size since the 1990s (Beaulaton et al., 2008).

The Portuguese Sea lamprey populations have decreased dramatically since the 1980s (Collares-Pereira et al., 2000). In the Tagus River, the decline in catches after the 1950s was mainly due to the huge reduction of the original spawning areas related to the construction of dams, but the recruitment of this species has also been affected by the pollution of some tributaries (Ferreira \& Oliveira, 1996).

Cobo et al. (2010) have described an increase in Sea lamprey ammocoete density between 2007 and 2009 in the Galician rivers, with higher densities and biomass in Cantabrian Slope rivers. In the Minho River, there is little knowledge about the larval phase, but we have noticed an increase in the abundance of adults captured since 2002 (Fig. 4). Official statistics of the Minho River small-scale fisheries indicated that the Sea lamprey is the only diadromous species that has exhibited increasing captures in recent years (Fig. 2). However, as of the late $19^{\text {th }}$ century in the international section of the Minho River, the Allis shad and Atlantic salmon fishery was more relevant both in quantitative and economic terms compared to the lamprey (Baldaque da Silva, 1892), with the latter gaining more expression from the 1960s. The quality of lamprey fishery data after that date may have been improved.

Although future trends remain unclear, Lassalle et al. (2008), using a niche modeling approach, predicted a decline in Iberian Sea lamprey populations. According to this study, the northern Spain and Adour basins could become, in the near future, the southern limit of the distribution of the Sea lamprey, which could disappear from Portuguese basins.

As the Sea lamprey adult phase is parasitic, feeding on large fish, it seems possible that the abundance of Sea lamprey may be associated with the abundance of suitable prey, particularly shad and salmon. According to Henderson (2003), the re-establishment of large populations of these migratory species in the rivers of a given region could help with the re-establishment of large populations of Sea lamprey. For example

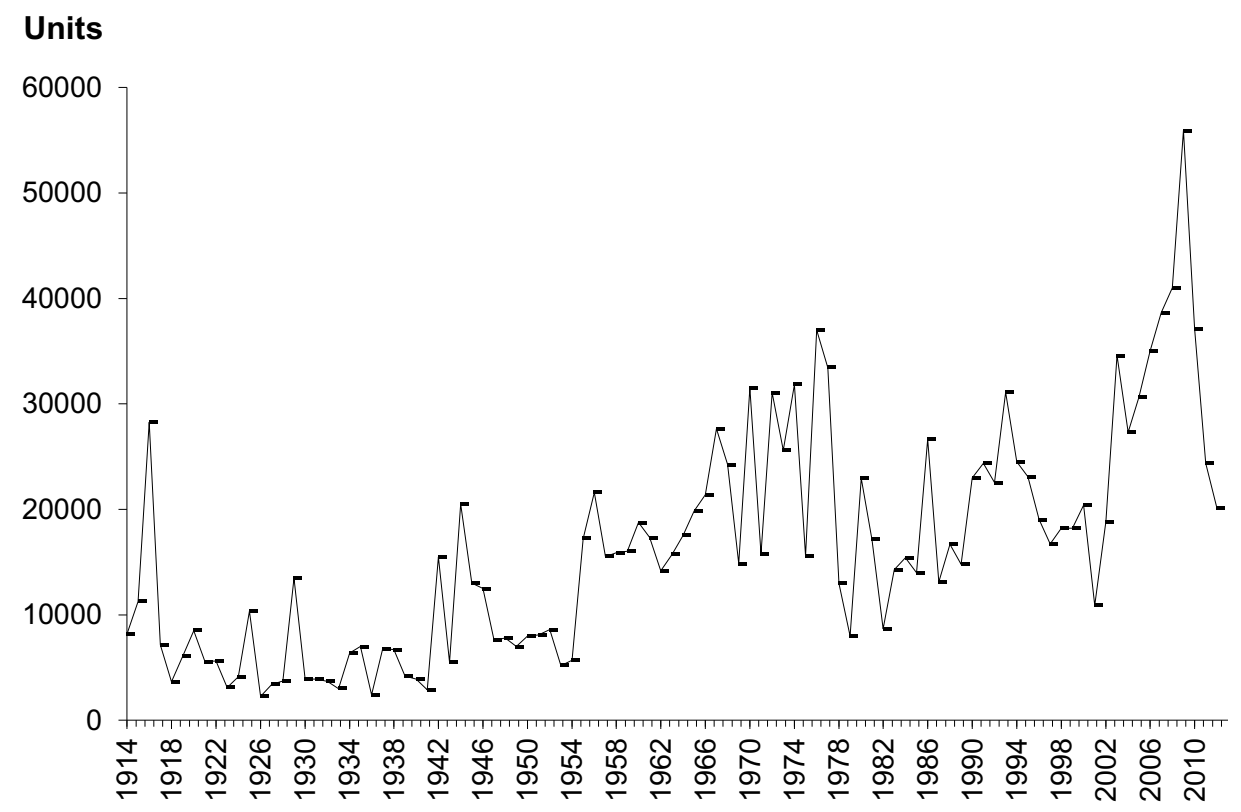

Figure 4. Time series of Sea lamprey catches (number) in the Minho River, reported by Portuguese fishermen to the local Maritime Authorities (source: Maritime Authority of the Caminha Fishing Harbour). Série temporal das capturas (número) de lampreia marinha no rio Minho, declaradas pelos pescadores portugueses à Autoridade Marítima local (fonte: Capitania do porto de Caminha). 
Silva et al. (2013) have documented haematophagus feeding of postmetamorphics on Twaite shad and salmon. However, further research is needed concerning these phenomena in order to explore these relationships, as a prey increase could be a way of preventing the disappearance of the Iberian Sea lamprey populations.

Based on recent genetic analyses that suggest differentiation between European and North American Sea lamprey populations (RodríguezMuñoz et al., 2004), Mateus et al. (2012) recommended managing both populations independently and proposed to revise the IUCN status of the European species.

\section{S. salar}

The current distribution of the Atlantic salmon S. salar (Linnaeus, 1758) ranges from Northern Portugal to North America. In the East Atlantic, the species can be found from northern Portugal $\left(42^{\circ} \mathrm{N}\right)$ to Petjorskoye in northern Russia (Jonsson \& Jonsson, 2009). Its range includes rivers in Spain, France, UK, Ireland, Norway, Sweden, Finland and other countries draining into the Baltic, as well as Iceland and Greenland (Hendry \& Cragg-Hine, 2003). Wild Atlantic salmon have disappeared from Germany, Switzerland, the Netherlands, Belgium, the Czech Republic and Slovakia basins (OSPAR, 2010). Comparatively healthy populations are known to be found in only four countries: Norway, Ireland, Iceland and Scotland (OSPAR, 2010). In the last 50 years, the Iberian rivers where salmon were present ranged from the Minho River (NW Portugal), the species' southern limit in Europe (Hervella, 2002; Álvarez et al., 2010), to the Bidassoa river (Basque country, North Spain). Formerly, the species could be found as far south as the Guadiana River (Doadrio et al. 1991;

Table 2. Migratory fish species occurring on the IP, the major threats affecting them, conservation status attributed by IUCN, Portugal and Spain and future trends. PT: Portugal; SP: Spain; LC: Least concern; VU: Vulnerable; CR: Critically endangered; EN: Endangered; DD: Data deficient; NA: not available; NP: Not present; IN: Increase; DC: Decrease. Espécies de peixes migratórios presentes na PI, suas maiores ameaças, estatuto de conservação atribuído pelo IUCN, por Portugal e Espanha e tendências futuras. PT: Portugal; SP: Espanha; LC: Pouco preocupante; VU: Vulnerável; CR: Criticamente em perigo; EN: Em perigo; DD: Dados insuficientes; NA: Não disponível; NP: Ausente; IN: Aumento; DC: Diminuição.

\begin{tabular}{|c|c|c|c|c|c|c|c|c|}
\hline & \multicolumn{3}{|c|}{ Confirmed presence in Iberian Peninsula } & \multirow[t]{2}{*}{ Main threats } & \multicolumn{3}{|c|}{ Present conservation status } & \multirow[t]{2}{*}{ Trend } \\
\hline & North IP & West IP & South IP & & $\overline{\mathrm{IUCN}}$ & PT & $\mathrm{SP}$ & \\
\hline P. marinus & $\begin{array}{l}\text { Cantabrian coast } \\
\text { (Asturias, Galicia) }\end{array}$ & $\begin{array}{l}\text { Galicia, } \\
\text { West coast } \\
\text { of Portugal }\end{array}$ & $\begin{array}{l}\text { Algarve and } \\
\text { Mediterranean } \\
\text { Spain }\end{array}$ & $\begin{array}{c}\text { Rivers } \\
\text { fragmentation } \\
\text { pollution }\end{array}$ & $\mathrm{LC}$ & VU & VU & IN \\
\hline S. salar & $\begin{array}{c}\text { Cantabrian/Galician } \\
\text { coasts (Bidassoa, } \\
\text { Asturias, Bask Country) }\end{array}$ & $\begin{array}{l}\text { Galicia, and } \\
\text { Minho river }\end{array}$ & NP & $\begin{array}{l}\text { Pollution, } \\
\text { dams, } \\
\text { overfishing }\end{array}$ & $\mathrm{LC}$ & $\mathrm{CR}$ & $\mathrm{EN}$ & DC \\
\hline S. trutta & $\begin{array}{l}\text { Asturias (Cantabria } \\
\text { and Galicia) }\end{array}$ & North of Portugal & NP & $\begin{array}{l}\text { Pollution, } \\
\text { dams }\end{array}$ & $\mathrm{LC}$ & $\mathrm{CR}$ & VU & DC \\
\hline A. alosa & Bidassoa, Asón & $\begin{array}{l}\text { North and } \\
\text { centre of } \\
\text { Portugal }\end{array}$ & NP & $\begin{array}{l}\text { Dams, habitat } \\
\text { loss, pollution, } \\
\text { overfishing }\end{array}$ & $\mathrm{LC}$ & En & VU & DC \\
\hline A. fallax & DD & $\begin{array}{l}\text { Galicia, } \\
\text { north and } \\
\text { centre of } \\
\text { Portugal }\end{array}$ & $\begin{array}{l}\text { Guadiana, } \\
\text { Ebro, } \\
\text { Guadalquivir }\end{array}$ & $\begin{array}{c}\text { Habitat loss, } \\
\text { pollution }\end{array}$ & $\mathrm{LC}$ & $\mathrm{VU}$ & VU & DC \\
\hline A. anguilla & All rivers & All rivers & All rivers & $\begin{array}{l}\text { Habitat loss, } \\
\text { pollution, } \\
\text { parasites and } \\
\text { diseases, } \\
\text { predation, } \\
\text { overfishing }\end{array}$ & CR & EN & VU & $\mathrm{DC}$ \\
\hline
\end{tabular}


Elvira, 2004; Álvarez et al. 2010). Presently, except for wandering migration events, which can occur in small N-Portuguese rivers, such as the Lima River, its southern limit of distribution is in the Minho River. Thus, the IP species inhabit, in a relatively permanent way, about twenty rivers covering the Cantabrian, Galician and Northern Portugal coasts between the Minho River and the Bidassoa River (Doadrio et al., 2011).

Álvarez et al. (2010) pointed out several negative impacts on the "salmonids" habitat in the IP: damage to riverine vegetation that causes a solar radiation increase and, consequently, water temperature rising; disappearing of spawning grounds and alevin habitats; and modification and disappearing of ponds where adults can rest during migration and change in the estuarine conditions. These threats affected particularly the Oria and Urumea (both in the Basque Country, north IP), the Pas (Cantabria, north IP) and the Nálon-Narcea (Asturias, north IP) basins.

The IUCN Red List of Threatened Species includes the Atlantic salmon globally as a "Least concern" species (IUCN, 2013). However, this conservation status needs to be updated. In Spain, it is considered to be an "Endangered" species (Doadrio, 2002), and in Portugal, it is considered to be "Critically endangered" (Cabral et al., 2006) (Table 2).
On the IP, as well as in other European regions, the first phase of the decline of salmon populations started in the $11^{\text {th }}$ century, continuing during the $20^{\text {th }}$ century (Álvarez et al., 2010). Cumulative and synergistic factors are recognized to be responsible for the populations' regression. The decrease of the water quality due to industrialization and the development of hydropower at the end of the $19^{\text {th }}$ century and during the $20^{\text {th }}$, as well as overfishing and illegal fishing with explosives, had devastating results and led to the disappearance of Atlantic salmon from many rivers of the North Iberian Peninsula (Álvarez et al., 2010).

In the Ulla and Lérez rivers, located in the southern part of the European distribution of wild Atlantic salmon, the populations have been seriously endangered since the late 1970s. By 1991, the River Lérez population was close to extinction (Saura et al., 2006). At the beginning of the $21^{\text {st }}$ century, Atlantic salmon migrated along only 32 Iberian rivers (Álvarez et al., 2010).

Official data of small-scale fisheries started to be available from the second half of the $20^{\text {th }}$ century. Since the 1970s, the IP has been facing a severe drop in catches. The Galician rivers have contributed to more than half of the salmon catches of all Spain and are the "salmonid" region par excellence (Hervella, 2002). They pro-

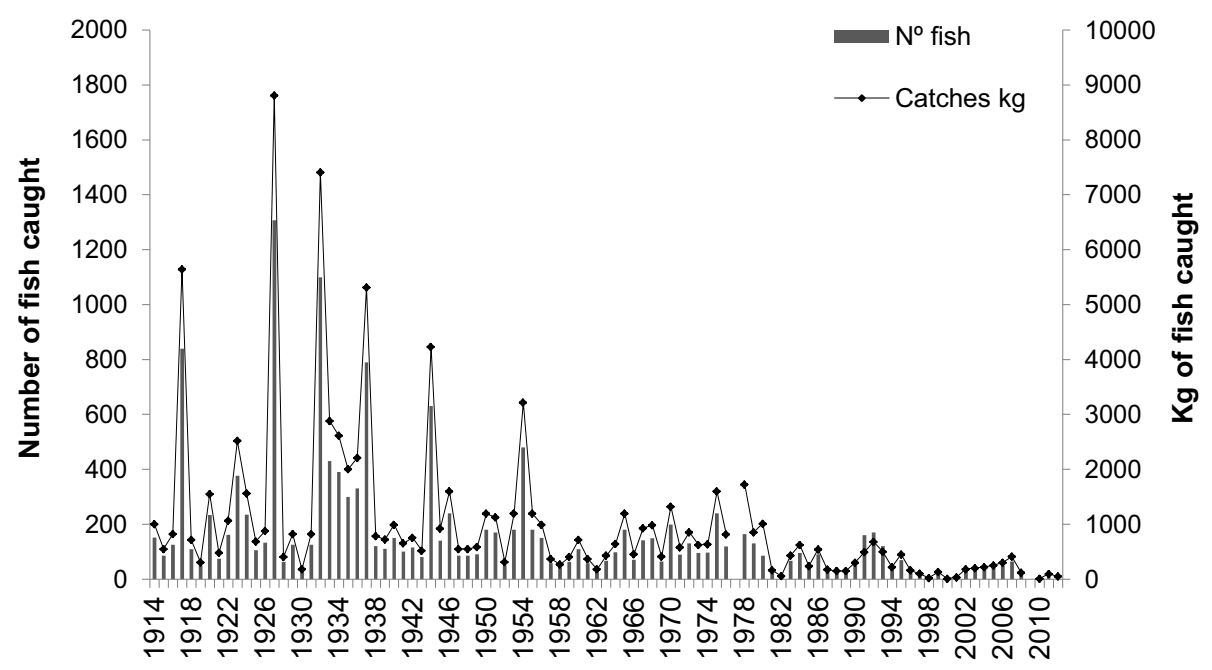

Figure 5. Time series of salmon catches (weight and number) in the Minho River, reported by Portuguese fishermen to the local maritime authorities (source: Maritime Authority of the Caminha Fishing Harbour). Série temporal das capturas (peso e número) de salmão no rio Minho, declaradas pelos pescadores portugueses à Autoridade Marítima local (fonte: Capitania do porto de Caminha). 
vided 12000 salmon per year in the 1920s and 1930s. At the beginning of the second half of the $20^{\text {th }}$ century, the total yearly catches in Galician rivers, including Minho (border between Portugal and Galicia, Spain), reached 2000 individuals in the most productive years. Since 1980, the average yearly catch has dropped to about 200 . The worst year was 1998, with only 26 salmon caught in all of Galicia (Álvarez et al., 2010) and North Portugal. In the latter region, until the 1990s, salmon populations were described for the Minho and Lima Rivers (Antunes \& Weber, 1990; Valente et al., 1991). It was estimated that less than 250 mature fish existed and that $90 \%$ of them belonged to the Minho population. The decline has continued along the last three generations, and accentuated fluctuations in the number of mature individuals have been realized (Rogado et al., 2006a). Currently, the Lima population is residual or even extinct.

The Minho River was the largest "salmonid" river of the Cantabrian-Atlantic slope and also the one with the largest production capacity. However, due to the construction of dams, the area used by the salmon now represents only $6 \%$ of the pristine favorable growth habitats (Hervella, 2002; Álvarez et al., 2010). Data supplied by fishermen indicated catches of about 1000 salmon per year in the $1^{s t}$ half of $20^{\text {th }}$ century. Since 1950, the catches in the Minho River dropped to 200-400 individuals and, in the last decades, did not exceed 100 fish per year (Álvarez et al., 2010). More recent statistics supplied by maritime authorities showed that catches in the Portuguese part of the Minho River did not exceed 64 individuals in the last ten years, with a minimum of only five individuals caught in the year 2000 (Fig. 2 and Fig. 5).

Although data from fisheries are now established more seriously, the state of salmon populations remains unclear for most of the IP Rivers. That is partly because few Iberian rivers have migration control devices and partly due to the lack of knowledge regarding fundamental aspects of the population structure, such as spawning populations and juvenile growing areas (Álvarez et al., 2010). However, a comprehensive restoration program for Atlantic salmon in some Galician and international rivers, including the Ulla, the Lérez and the Minho, began in 1995 (Caballero, 2002a).

The results of stocking programs are variable and have been amply documented (see Fraser, 2008), whereas cases of natural recolonization by Atlantic salmon are rare and have been described only in small- or medium-sized river systems (Vasemägi et al., 2001; Saura et al., 2006; Saura et al., 2008).

As Atlantic salmon is a cold water species, it is likely that populations inhabiting the natural southernmost edge of the distribution range will be extremely endangered or even become extinct, due to the combination of several threats experienced over the past centuries and the recent climate change effects (Lassalle \& Rochard, 2009; Álvarez et al., 2010; Valiente et al., 2010).

\section{S. trutta}

The Sea trout S. trutta (Linnaeus, 1758), an anadromous form of brown trout, is a fish of high commercial and ecological value in Europe. This form has a wide range of distribution and is found throughout the range of the Atlantic salmon in continental Europe, on the British Isles, and in Scandinavia and Iceland. The Sea trout occupies rivers in the northwestern quadrant of the Iberian Peninsula, with the Minho River (latitude $42^{\circ}$ ), North Portugal, which is considered to be the southern limit of its natural distribution (Caballero et al., 2006; Milner et al., 2006a; Okumus et al., 2006; Caballero, 2002b; Elliott, 1989). In the first half of the $20^{\text {th }}$ century, Sea trout also occurred in the Cávado River (Southern of the Minho River), but populations have disappeared or have been reduced to extremely low numbers as a result of various pressures (Valente et al., 2000). Today, the only functional population of Sea trout is the one in the Minho River.

Sea trout is reasonably abundant and widespread in European rivers, supporting important sport and commercial fisheries (Euzenat et al., 2006). Although not all aspects have been addressed, it is an extensively studied fish (e.g., Nikolic et al., 2011; Pettersson et al., 2001; Euzenat 
et al., 1999; Lyse et al., 1998; Johnstone et al., 1995; Solomon, 1995; Lund \& Hansen, 1992; Hindar et al., 1991; Dellefors \& Faremo, 1988). Long-standing studies have been performed on the North Esk, Scotland (Pratten \& Shearer, 1983), Black Brows Beck in Cumbria, England (Elliott \& Elliott, 2006), and in Burrishoole, Co. Mayo, Ireland (Poole et al., 2006). These studies were afterwards complemented by studies on the Rivers Bresle (Euzenat et al., 2006) and Oir (Acolas et al., 2008), France. However, these studies mainly focused on the North-East Atlantic populations, and there is a lack of scientific literature on Iberian populations. To date, few references can be found on the Iberian stock characteristics (Toledo et al., 1993; Caballero et al., 2006). Indeed, scientific studies situate the Sea trout's natural distribution range between latitude $48^{\circ} \mathrm{N}$ and $62^{\circ} \mathrm{N}$ (Jonsson \& L'Ábée-Lund, 1993; Richard, 1986), leaving a large gap between the latitudes $42^{\circ}$ (Minho River mouth) and $48^{\circ}$ North (Normandy coasts) (Caballero, 2002b). For the IP, only few studies were conducted. There are some references to the Asturian population's life cycle (Alvarez-Riera, 1985; Toledo et al., 1993). Caballero (2002b) describes the Iberian Sea trout life cycle for the first time, and Caballero et al. (2002) compares some Sea trout biological variables with salmon populations.

The status of Sea trout stocks and fisheries varies across its range, depending on the influence of local factors (Milner et al., 2006b). Sea trout stocks seem to be healthy in some regions, but there have been major collapses in others (Harris \& Milner, 2006), with a decline in trout populations found in numerous places (e.g., Aarestrup \& Jepsen, 1998; Jutila et al., 2006; Okumus et al., 2006).

Worldwide, many Sea trout stocks are extinct or are facing extinction because of anthropogenic impacts, i.e., environmental degradation, damage of spawning areas and interruption of spawning migrations (dam constructions), deforestation, drainage, straightening and channelling of watercourses, overfishing and poaching (see Landergren, 1999; Lundqvist et al., 2006; Okumus et al., 2006).
Sea trout collapsed in the Midwest Irish region and in Scotland in 1988-1990 (Butler \& Walker, 2006; Gargan et al., 2006). The same occurred in many other western Sea trout fishery areas, where the collapse of populations started in 1989 (Gargan et al., 2006). The areas, which have seen the greatest declines in Sea trout, coincide geographically with the development of salmon aquaculture. Although no direct link has yet been established, there is an increasing concern about the possible links between the sea lice disease and its effect on wild salmonid host stocks (Gargan et al., 2006).

Threats to Sea trout should be considered seriously. There is an urgent need for the development of an integrated management and conservation strategy. Prevention of further decline through effective fishery enforcement is essential to preserve the remaining stocks, but this will require integration between different agencies and countries and shared aims and a common strategy (Okumus et al., 2006).

The high variability of life-history patterns of $S$. trutta, their iteroparity and specially the lack of understanding regarding the relationships between resident and anadromous brown trout stocks within the same catchment have hindered attempts to establish realistic stock-recruitment relationships (Poole et al., 2006).

An effort has to be made to preserve and prolong long-term studies, so that essential background data for the interpretation of short-term fluctuations and trends can be obtained and made available (Euzenat et al., 2006). Baglinière and Maisse (2002) demonstrated that, from a functional point of view, headwater streams are very important in the recruitment process of Sea trout in a basin population and claim that there is a need to maintain their physical integrity. They have also demonstrated that ensuring a free movement of fish between the main stem and tributaries of a stream is important for growth and breeding.

Regarding the IP, Sea trout is especially important in Galician and North Portuguese (particularly in the Minho River) rivers. Here, Sea trout are ubiquitous and represent an important natural resource, as well as an important sport fish- 
ery fish (Hervella \& Caballero, 1999; Caballero et al., 2006). Populations have been described for the Minho and Lima rivers (Antunes \& Weber, 1990, Valente \& Alexandrino, 1990). Information collected from fishermen indicated that the number of mature individuals is extremely limited and that both sea and brown trout are in continuous decline in these two basins (Rogado et al., 2006b).

In Portugal, the reduction of Sea trout populations over the past 10 to 15 years has reached $98 \%$ of mature adults, and it is expected that this declining trend could persist for the next 10 to 15 years (Rogado et al., 2006b). The causes for the reduction, though generally understood, are not reversible and have not been eliminated. The evaluation of the population decline is based on abundance data, reduction of the area of occupancy, extent of occurrence and habitat quality and on the expansion of non-native species (Rogado et al., 2006b), such as rainbow trout (Oncorhynchus mykiss). The realization of any stock- ing programs in these basins should preferably use the eggs or alevins from the same population or, at least, close populations, preventing the import of non-indigenous populations that are genetically different (Antunes et al., 2001).

As a natural resource, Sea trout have a socioeconomic value that exceeds that of salmon in some areas (Milner et al., 2006b). Given the social and economic value of Sea trout fisheries, stocks need to be conserved and associated fisheries need to become sustainable (Walker et al., 2006). Stocking programs, such as those performed in Scotland (see Lundqvist et al., 2006; Hay \& Hatton-Ellis, 2006), should hence be taken into account to maintain and preserve Iberian Sea trout populations.

\section{A. alosa and A. fallax}

Historically, the distribution of Alosa species covered the eastern Atlantic from Norway to Morocco and the Western Mediterranean Sea. From

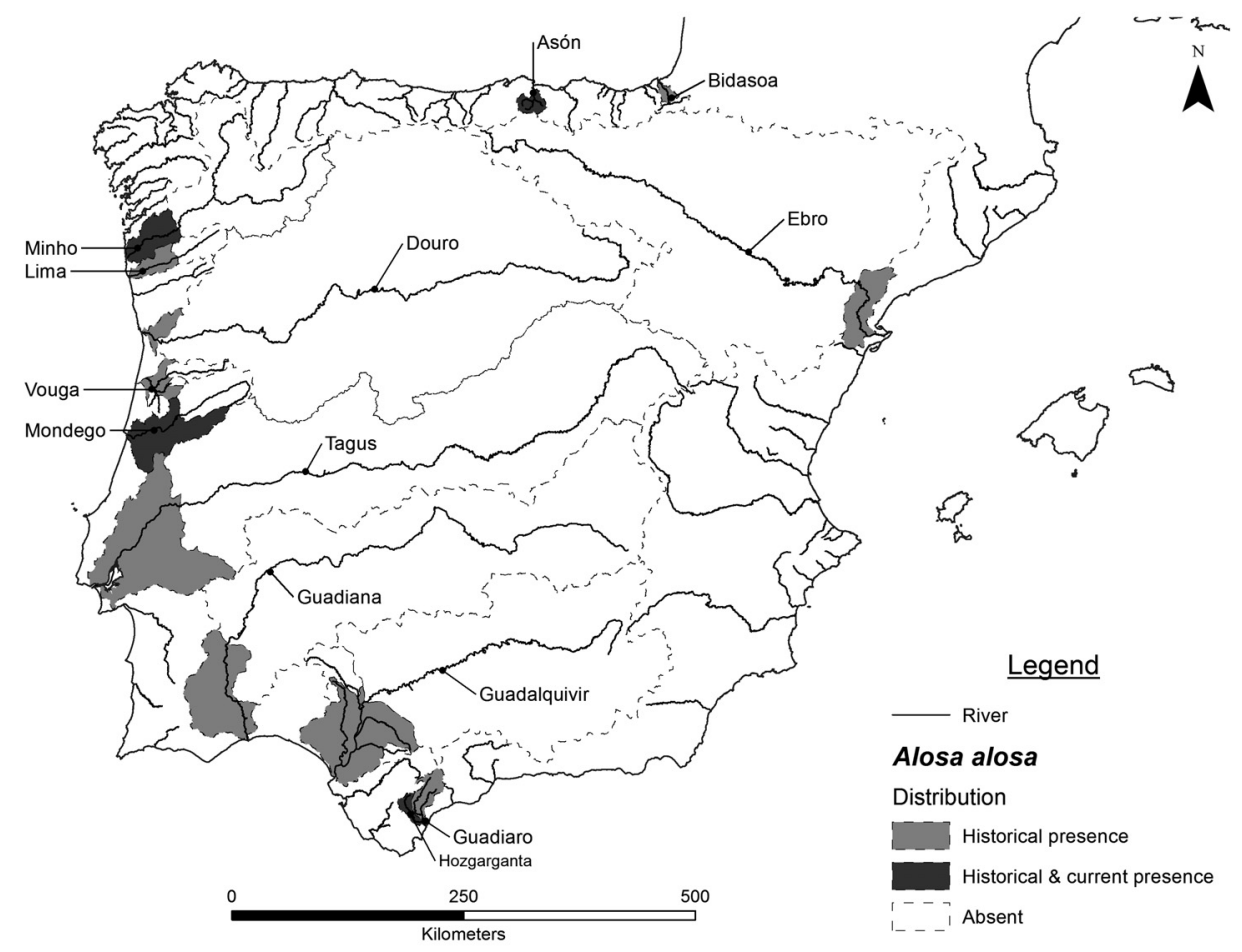

Figure 6. Historical and current distribution of the Allis shad on the Iberian Peninsula. Distribuição, histórica e atual, do sável na Peninsula Ibérica. 
the middle of the $20^{\text {th }}$ century, a clear contraction of the natural distribution range was observed, and nowadays, Allis shad A. alosa (Linnaeus, 1758) is restricted to the Atlantic coast of France and Portugal (Baglinière, 2000). Currently, the northern limit of spawning stocks areas is the Vire Basin in Normandy and the southern limit is the Minho, located at the boundary between Portugal and Spain (unpublished data).

On the IP, shad populations are more frequent at the Cantabrian and Atlantic coasts than at the Mediterranean coast (Table 1). Allis shad, once found in all major Iberian rivers (Doadrio, 2002, Doadrio et al., 2011), is now rare, much reduced or virtually extinct in most of the rivers (Fig. 6). In Portugal, the Minho River population seems to be one of the most important populations of the southern part of its distribution, although Allis shad has been described to be present in the Vouga and Mondego (Faria, 2007) rivers, for which little data are available.

General literature reports suggest the presence of Alosa spp. in Galicia (Spain), but detailed information about which species are present in the river systems is restricted to the presence of A. alosa in the River Minho (Mota \& Antunes, 2011; 2012; Mota et al., 2015) and of A. fallax in the river Ulla (Silva et al., 2013; Nachón et al., 2013). In addition, Spanish sport fishermen report the existence of important Alosa spp. populations in some Northern Spanish rivers that were never studied, such as the Anllóns and Eo rivers (Nachón, pers. conv.).

Historically, Allis and Twaite shads were of great economic importance, but currently, the Galician populations are severely impacted (Hervella \& Caballero, 1999). Portuguese shad populations suffered an evident decline since the middle of the $20^{\text {th }}$ century, particularly in the Minho and Lima rivers.

The main reasons for this decline have been the construction of dams, which, next to preventing access to spawning grounds, prompt the hybridization with Twaite shad; the permanent loss of suitable habitat; the generalized pollution of aquatic systems, especially in the lower reaches and estuaries; and overfishing (Aprahamian et al., 2003, Rougier et al., 2012).

The decline of Portuguese Allis shad populations has also been related to the reduction of river flows and overfishing of the most important stocks (Costa et al., 2001). Legal and illegal by-catch of juveniles by glass eel fisheries and other fisheries (Antunes \& Weber, 1996; Assis et

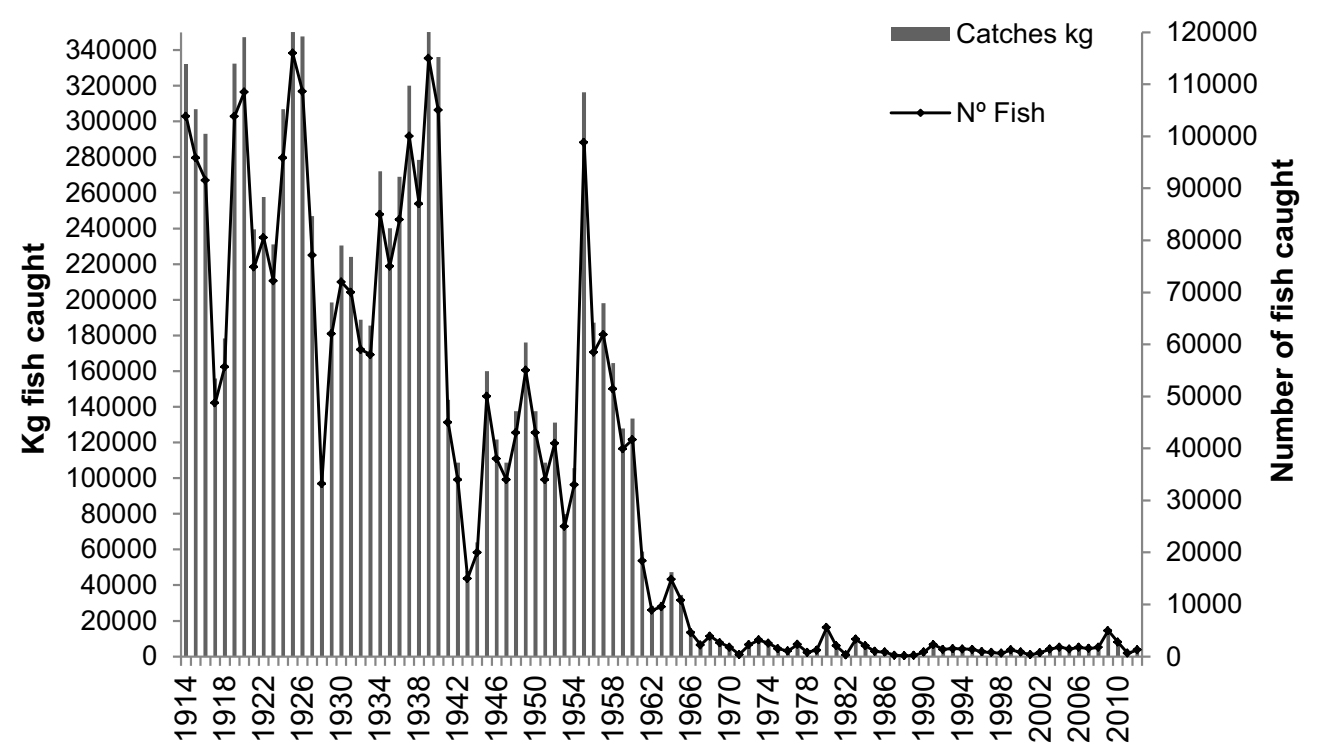

Figure 7. Time series of Allis shad catches (weight and number) in the Minho River, reported by Portuguese fishermen to the local Maritime Authorities (source: Maritime Authority of the Caminha Fishing Harbour). Série temporal das capturas (peso e número) de sável no rio Minho, declaradas pelos pescadores portugueses à Autoridade Marítima local (fonte: Capitania do porto de Caminha). 
al., 1992) and hybridization between A. alosa and A. fallax (Alexandrino, 1996) were also reported as a major constraint to Portuguese shad populations.

The gradual decrease of Alosa spp. in several European basins, caused essentially by anthropogenic pressures, led to its listing in the Red List of the International Union for the Conservation of the Nature (IUCN), in Annex III of the Bern Convention, and in the Habitats Directive (Annex II).

In Spain, the Alosa species (A. alosa and A. fallax) are classified as vulnerable in the Red List of the Vertebrates of Spain (ICONA, 1986), in the Red Book of the Vertebrates of Spain (Blanco \& González, 1992) and in the Atlas and Red Book of the Continental Fish of Spain (Doadrio, 2002). At the regional level, in Galicia, they are listed as an endangered species (Viéitez \& Rey, 2005). In Portugal, A. fallax is classified as a vulnerable species and A. alosa as endangered (Cabral et al., 2006), and they are now under legal protection.

Within the IP, the Minho was once the river with the highest catches of Alosa species (Baldaque da Silva, 1892), and $A$. alosa still has a great commercial and heritage value in the Minho River basin (Mota \& Antunes, 2011; Mota et al., 2015).

Official statistics from the Portuguese maritime authorities for the Minho River small-scale fishery show yearly mean catches of 200 tonnes of $A$. alosa during the first half of the $20^{\text {th }}$ century, with peaks of 300 tonnes (Mota \& Antunes, 2011; Mota et al., 2015). After the 1950s, catches decreased by about $90 \%$ (Fig. 7), coinciding with the building of the first dams (Alexandrino, 1996; Baglinière et al., 2003). The last dam was built in 1969 , confining the accessible main course of the river Minho to $80 \mathrm{~km}$; this dam is now the first physical barrier faced by Allis shad.

Even though the captures in the last decades never rose to the original values, the same source shows peak catches of about 18 tonnes in 1980 and 16 tonnes in 2009. However, it is broadly known that these data could be underestimated due to the lack of reliable official statistics. Unofficial Portuguese and Spanish data over the last eight years indicated that catches may have been twice as high (Mota \& Antunes, 2011), but the general trend is the drop of long-term catches
(Fig. 2 and Fig. 7). Nonetheless, the Allis shad of the Minho River is still of high commercial and heritage value, and information from fishermen confirms the existence of a shad population worth preserving.

Next to the loss of habitat, one of the major threats to the Minho River Allis shad population is overfishing and poaching. In this sense, it could be important to improve our knowledge of the species marine phase, as there is evidence of bycatch by marine fisheries. On the other hand, the habitat loss imposed by the first Minho River dam limits the river's carrying capacity and can lead to hybridization with A. fallax. Alexandrino (1996) reported high levels of introgression in a close population, i.e., the Lima River population. Recent morphometric works on the Minho Allis shad population demonstrated an average of $5 \%$ of hybrids among spawners and 19\% of hybrids among the young of the year (YOY) (Mota et al., 2015).

Preliminary and pioneer biological and ecological studies of Allis shad in the Minho River (Mota \& Antunes, 2011; 2012; Mota et al., 2015) already provide some guidelines for future management and conservation of this species, which should primarily be based on cross-border cooperation protocols and joint measures. As habitat loss is one of the major causes for population decline, the knowledge of YOY Allis shad growth areas could be considered as a key factor in determining its abundance (Mota \& Antunes, 2012). The location of spawning grounds and juvenile growth habitats allowed for identification of "sanctuary areas". The restriction of sport fishing in these areas and of commercial fishing in other critical areas, as the river mouth and locations with reduced distances between banks, may help with the success of recruitment. On the other hand, as the spawning grounds of this population are below the first dam (Mota \& Antunes, 2012; Mota et al., 2015), the regulation of dam flow is essential for the survival and recruitment of this river's Allis shad population. Unfortunately, the ecological value of water discharge is managed by the hydro-power company and the dam's fish ladder does not work in terms of upstream fish passage. 
Furthermore, a better understanding of the introgression level of the specific upstream and estuarine habitat requirements for the growth of YOY Allis shad, as well as reliable marine and riverine catch statistics, would allow managers to plan conservation and protection strategies.

\section{A. anguilla}

The European eel A. anguilla (Linnaeus, 1758) is present in all watersheds but is strongly limited by dams. On the Iberian Peninsula, the eel has disappeared from most of the Ebro, Tagus, Douro and Guadiana catchment areas (Doadrio, 2002). Large-scale surveys by the early 1980s showed that the eel became extinct in more than $80 \%$ of the Iberian rivers (Lobón-Cervia, 1999), and it is presently absent from central Spain (Nicola et al., 1996) and Portugal.

The abundance of riverine stocks of European eel depends entirely on the annual recruitment of the youngest juveniles (i.e., glass eels) reaching continental waters. In general, the eel density decreases with distance to the river mouth (Lobón-Cervia et al., 1995) and varies interannually and between different rivers. Bernat et al. (1987; 1988) found 1535-1891 ind./ha and 3031-4063 ind./ha in the Esva basin. In the River Esva eel, density was estimated to be 1300-2120 ind./ha (Lobón-Cerviá et al., 1995). In Minho River tributaries, the average density of yellow eels was 1083 ind/ha (Antunes et al., 2012).

Although European eel still seems to be common in many areas (mainly due to transfer of individuals) (Antunes et al., 2012), the species is subjected to several threats. The main threats include fisheries, stream migration blockages, loss of habitat, pollution, parasites and diseases, predatory birds, as well as climatic changes in their environment especially during their larval marine migration (OSPAR, 2008). During the 1980s, commercial fishing declined in the whole of Europe (Fig. 8).

In the Atlantic, the most important glass eel fishery basins are the Minho, the Asturian basins, the Basque river basins and the Guadalquivir. However, in the Mediterranean, the most important glass eel fishing points are the Delta of the Ebro and the Valencian Albufera (Díaz \& Castellanos, 2007; Domingos \& Antunes, 2011). Indeed, contrary to what happens in Portugal, where glass eel fishery was forbidden in 2000, in all river basins except for the Minho River where it is still allowed, in Spain, the glass eel fishery exists in all Region Basin Demarcations (RBDs). However, there are different statutes among fishermen. For instance, Basque fishermen cannot sell their catches and should therefore be classified as non-professional. In Cantabria, both professional and recreational glass eel fishery exists, mainly located in the Nansa (Pasand). The glass eel fishery is a very traditional fishery in the Asturias and Galicia/North Portugal region (Minho River) (Domingos \& Antunes, 2011; Andonegi et al., 2011). Despite the efforts of the Portuguese authorities, resulting in the confiscation of a large number of nets, poaching remains a problem all over the country, especially in the northern and central parts of Portugal (Domingos \& Antunes, 2011).

In addition, there are important yellow and silver eel fisheries in Galicia, C. Valenciana, Catalonia and Portugal. There is no professional yellow or silver eel fishery in the Basque Country, Asturias, the international section of the Minho River and Cantabria. In these regions, recreational fishery was furthermore forbidden in 2009, 2007 and 2011, respectively, and it is negligible in Cantabria. In Portugal, yellow eel fishery is ruled by eleven specific bylaws applied to eleven fishing areas in coastal waters (estuaries and coastal lagoons) and nine other bylaws, which are applied to specific fishing areas in inland waters. These define the river stretches where fishermen are allowed to fish and lay down fishing rules (gears and mesh sizes, the size limit of the species, hour restrictions and species restriction).

Considering chemical pollution, eels presenting a high contaminant burden, including heavy metals and low energy stores, may reveal migration failure and/or reproduction impairment (Belpaire \& Goemans, 2007), and they may also be more susceptible to diseases (Langston et al., 2002). A few studies were done on heavy metals in eel from the IP, considering the risk for human 
consumption (Establier, 1975; Rico et al., 1987; Sánchez et al., 1994, 1998; Linde et al., 1999; Usero et al., 2004; Urena et al., 2007). In general, the values obtained in the edible portion of eels stayed below the maximum limits allowed according to EU regulations, and consequently, regarding possible effects of the studied metals, human consumption of these fish should be safe (Neto et al., 2011). Different IP basins reveal the following pesticides: Albufera in Valencia (Ferrando et al., 1992), organochlorine residues in Doñana (Rico et al., 1987) and in Cantabria (Guitart et al., 2005), the Ebro delta (Ruiz \& Llorente, 1991) and River Turia (Bordajandi et al., 2003), mercury in Cadiz (Establier, 1975), and PCBs in Ria Aveiro (Antunes \& Gil, 2002) and River Turia (Bordajandi et al., 2003).

Concerning parasite infection, the nematode Anguillicoloides crassus is a pathogenic helminth potentially representing an additional factor in the decline of eel populations (Münderle et al., 2004; Kennedy, 2007). In fact, A. anguilla is unable to develop an effective immune response against $A$. crassus (Taraschewski, 2006). The nematode is widespread on the IP. Data were reported on parasites and pathogens in
Spanish Mediterranean basins, Asturias, in five Portuguese brackish water systems (Aveiro Lagoon, Óbidos lagoon, Tejo estuary, Santo André Lagoon and Mira estuary) and the Minho River. The A. crassus prevalence values ranged from $1.7 \%$ to $100 \%$ (Andonegi et al., 2011; Domingos \& Antunes, 2011). Pathogenic bacteria can play a leading role in the decline of such eel populations because all bacterial diseases were found to be as prevalent as swim-bladder disease; however, bacterial pathogens are strongly virulent for European eels. The youngest eels are the most susceptible to acute bacterial diseases, and they may suffer mortality in natural habitats (Esteve \& Alcaide, 2009).

Apart from the fish species Lusitanian toadfish (Halobatrachus didactylus) that can predate on eels (Costa et al., 2008) and the European eel, which can display cannibalistic behavior (Domingos et al., 2006), the main predators of eels in IP aquatic systems include the great cormorant, Phalacrocorax carbo, and the European otter, Lutra lutra (Trigo, 1994; Beja, 1996; Cerqueira, 2005; Dias et al., 2012). Dias (2007) estimated a consumption of 2.2 tonnes of eels by the great cormorant in the Minho River for the

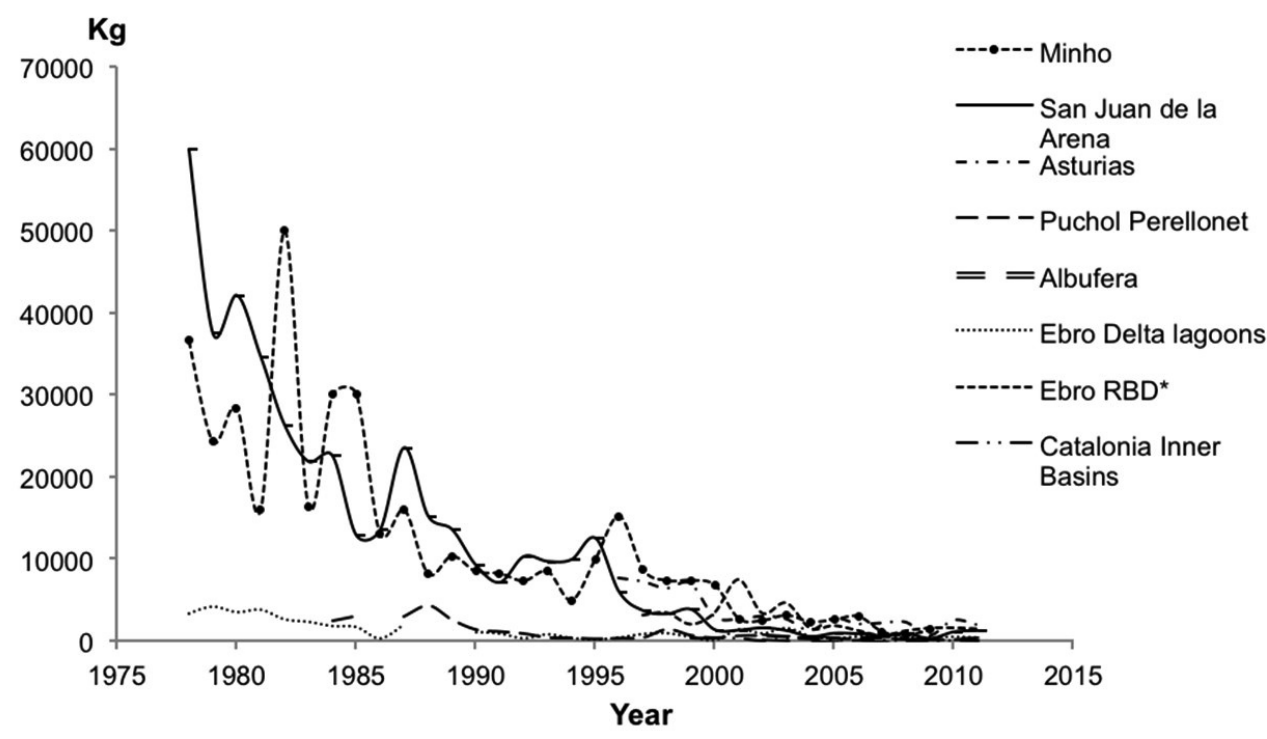

Figure 8. Time series of glass eel fishery (in $\mathrm{kg}$ ) for the IP (modified from Andonegi et al., 2011) (*RBD-Region Basin Demarcation). Série temporal da pesca de enguia de vidro (kg) na PI (modificado de Andonegi et al., 2011) (*RBD-Demarcação da Região de Bacia). 
period between October 2005 and March 2006.

The eel is considered as a "Vulnerable" species in Spanish and "Endangered" in the Portuguese Red Data Book (Blanco \& González, 1992, Cabral et al., 2006) (Table 1) and Annex II of CITES since 2007.

The assessment of glass eel fisheries by local administrations, reinforced by the activities of the ICES/EIFAC Working Group on Eel (Braum \& Tesch, 1990), has been instrumental in detecting long-term trends in glass eel catches. Analysis of these data sets also revealed a steep decline in the capture of glass eels in rivers flowing on the two sides of the Atlantic Ocean (Hagstrom \& Wickstrom, 1990; Moriarty, 1990; Castonguay et al., 1994; Moriarty, 1996; Moriarty \& Tesch, 1996; Antunes \& Weber, 1996).

In Spain, each autonomous government is in charge of the control, regulation and management of eel fishery and population. The only information that is compiled routinely corresponds to fisheries. In addition to that, each autonomous region has its own methodology to compile fishery data (Andonegi et al., 2011; Domingos \& Antunes, 2011). Portugal has delivered two Eel Management Plana (EMPs) to comply with the needs set by the Eel Regulation 1100/2007 (Domingos \& Antunes, 2011). One of those plans was established at the national level for the entire country, and the other one was the transboundary EMP for the international part of the Minho River, and both were already approved by the European Union.

\section{CONCLUSION}

During their life histories, diadromous species pass through and use a wide range of freshwater, marine and estuarine habitats and often cross numerous international borders. Identifying appropriate protective measures for poorly known species is practically unfeasible (McDowall, 1999). Nevertheless, general measures, such as providing healthy habitats and restoring connectivity, are valuable whatever the migratory species.

From an ichthyological point of view, the IP is extremely attractive. Apart from the great variety of endemic freshwater fish species (e.g. Elvira, 1995), the IP comprises several diadromous fish species in numerous rivers, which are economically valuable species, especially those described here. As seen in the last decades, there has been a global declining trend in the abundance and distribution of diadromous fish in the IP, following the tendency also observed in the rest of Europe and worldwide.

It is clear that the decline of numerous diadromous species cannot be attributed to a single factor acting individually, but to several factors acting simultaneously. Barriers to migration, habitat destruction (e.g., gravel extraction), overfishing and pollution have caused a loss of suitable space and of connectivity between vital habitats.

Furthermore, climate change, pointed out as a disturbance to the thermal regime of aquatic habitats, can alter the distribution of fish species and their assemblages as well as species richness in each basin (Taverny \& Elie, 2009). Representing the southern limit of the distribution of several species, the IP will undoubtedly experience the most marked effects of climate change in terms of river assemblages.

Although information on the conservation status, migratory behaviour, biology, genetics and ecology of diadromous fish still remains deficient (e.g., the Minho River shad and Sea lamprey populations have been studied only recently by Araújo et al. (2013a; 2013b; 2013c), Mota \& Antunes (2011; 2012) and Mota et al. (2015)) and further research is needed, it is obvious that the general trends for these Iberian populations are declining and that most of the species may disappear from most of their natural Iberian distribution range.

Additionally, most of the larger Iberian rivers, such as the Minho, Lima, Douro, Tagus and Guadiana, cross international borders, requiring the management and conservation status of migratory fish species to be improved through international cooperative efforts. Cooperation between the range countries in promoting research, awareness and cross-border management of migratory fish is of vital importance, as these activities may further enhance conservation results for this group of species. 
As pointed out by Cooke et al. (2012), when looking for migratory fish that cross international borders or that are part of shared stocks in international river basins, one of the most important management requirements is to develop concerted actions to regulate fisheries and maintain river health. If these actions are not effective, transboundary migratory fish populations may be particularly vulnerable to several threats such as overfishing (often occurring in nursery and breeding areas, and on migration routes), loss of habitat and connectivity between vital habitats, and alteration of river base conditions, such as water quantity, flow, and temperature (Cooke et al., 2012). One of the best examples of concerted actions aimed at ecological restoration was developed by the states bordering the Rhine River and included restocking of extinct fish species such as Atlantic salmon and Allis shad (Van Dijk, 1995; Beeck et al., 2008).

In the Iberian context, the Standing Committee of the International Stretch of the Minho River is an example of international fishery management cooperation. It regulates the small-scale fishery and sport fishing activities, although the regulations refer only to the international segment of the Minho River. Considering the effectiveness of conservation actions, governance structures are likely to be more successful if they recognize the connectivity of systems regarding shared hydrological basins.

\section{ACKNOWLEDGMENTS}

The authors acknowledge the "Encoro do Con" Station of Hydrobiology (University of Santiago de Compostela) staff, especially David Nachón, Sérgio Silva, Rufino Vieira-Lanero and Fernando Cobo, for helping with the bibliographic search, Rodrigo López for producing the maps, Ana Bio for producing charts and the Maritime Authority of the Caminha Fishing Harbour for providing fishery data. The authors also thank Gabriela Cunha and Ana Bio for the revision of the English language and the reviewers for their constructive comments. Micaela Mota was supported by a $\mathrm{PhD}$ grant from the Portuguese Foundation for Science and Technology -FCT (SFRH/BD/44892/2008). This research was partially supported by the European Regional Development Fund (ERDF) through the COMPETE - Operational Competitiveness Programme and national funds through FCT - Foundation for Science and Technology, under the project PEst-C/MAR/LA0015/2013.

\section{REFERENCES}

Reference list available at www.limnetica.com 